\title{
Research on the Problem of Internal Control Audit and Accounting Information Quality
}

\author{
Wang Hongni \\ Dongying Vocational College, Dongying, Shandong, China, 257091 \\ 54892713@163.com
}

Keywords: Internal control audit, Accounting information quality, Problem

\begin{abstract}
Internal control audit is a kind of internal control measures. From the internal of the enterprise, the internal control audit makes use of the internal management norms to control the enterprise. It is mainly used to evaluate and control the enterprise problems occurring from the beginning to the operation. It can be divided into control design and control operation. And then according to the problems of different stages, the enterprise finds out the corresponding measures and opinions, and finally realizes the effective control. This article will mainly elaborate the relationship between the internal control audit and the accounting information quality, and finally realize the solution to the problem of accounting information quality.

The quality of accounting information is an important basis for internal control audit. As it is the basis of internal control audit, we should accurately grasp the characteristics of internal control audit, grasp the quality of accounting information, and put forward reasonable improvement measures according to the problem to help the internal control audit achieve the best results and objectives. The definition of accounting information quality is different in different countries and organizations. But one thing is sure that the accounting information meets the sum of the characteristics of the needs of the explicit and implicit.
\end{abstract}

\section{General Features of Accounting Information Quality}

Usefulness of Accounting Information. Firstly, accounting information is a kind of basic information, which reflects the internal operation of the enterprise or the company. Its ultimate requirement is the real reflection of the operation of the enterprise. So the first feature of accounting information quality is useful, which can be used as a basis for the information given to the company's policy makers to provide the correct basis for. Secondly, the usefulness of accounting information quality is also reflected in the final implementation of the decision-making results. That is to say, the right useful accounting information will have a positive and far-reaching impact on the efficiency of the enterprise in latter stage.

Timeliness of Accounting Information. The quality of accounting information includes the timeliness of information. The accounting information must be useful. Moreover, it also should be timeliness information. If the delay of accounting information is relatively large, or simply does not meet the actual operation of the enterprise at this stage of the accounting information, it will lead to improper decision-making, to bring serious impact on the enterprise. With the arrival of the era of economic and information can be said is leaps and bounds, or the second information, and in the next second will lose its effectiveness. Therefore, the timeliness of accounting information is very important. The quality of accounting information is to minimize the time delay, the greatest degree of reduction of the impact of time, as far as possible the information back to the decision in the hands of. According to the characteristics of the market economy development and change, the entrepreneur combines the accounting information with the present situation of the enterprise to make the correct development decision.

Truthfulness of Accounting Information. The truthfulness of accounting information can reflect the actual situation of enterprises, and reveal the internal relations and influence of various economic factors. Authenticity can not only reflect all kinds of problems, but also directly affect the quality of accounting information. Wrong accounting information, not only will affect the 
decision-making and development direction of the enterprise, but also lead to the decision-making and enterprise demand far, not only cannot help the development of enterprises, but also to the development of enterprises to bring serious obstacles. According to dialectical materialism, nothing is absolute and everything is relative. Things are always developing and changing. So the truthfulness of accounting information is relative.

First of all, the authenticity of accounting information is closely related to the usefulness of the information. Accounting information is only useful in the premise, to say that the accounting information is true. If the accounting information is not useful, or the use of the value is little, that such accounting information can also be said to be untrue as it has no value use. Secondly, the authenticity of accounting information is each one according to his lights. Different accounting personnel, different cultural quality, different thinking mode, different working background will have different understanding of the truthfulness of accounting information. So it can be said that the authenticity of the accounting information is different people have different views. There is no absolutely real accounting information, but there is suitable information for the development of enterprise.

Accounting calculates the economic activity by the monetary unit. Accounting focuses on the relationship between the income and expenses of the enterprise, and the minimum investment in exchange for the maximum profit. As the purpose of the enterprise is profitable, the accounting looks like a full-time doctor of a business enterprise. It is the responsibility of the money to manage, good account, to ensure that every penny of real being used up. Although the profits of enterprises should be measured in terms of money, all enterprises should use money to measure, as well as the credibility of the enterprise, authority, visibility and so on. It is also a kind of intangible assets, or a priceless asset. Take a true story for an example.

Before the Wenchuan earthquake, there is a steel plant in Tianjin. The steel plant was not very big and can only be considered a medium-sized enterprise. Its boss is not particularly rich. After the earthquake in Wenchuan, he immediately donated to the epicenter of the destruction of the most serious areas, and the amount is quite large. At the same time, he shipped their steel to the disaster areas to support the victims. In fact, in the eyes of a full-time accounting, this is definitely a difficult task, because not only did not earn a penny, their businesses also lost so much money, it seems that the quality of accounting information. But on the contrary, because of the entrepreneur's gesture, many domestic enterprises in need of steels are to contact him, even though no cash to pay, they are also willing to believe him. Because his act is priceless, he do is corporate conscience, the conscience of products. It can be seen that the things for the authenticity of accounting information is a matter of opinion, starting from the point of view of accounting information, the loss of the sale does not worthwhile, but from the social benefit of, this kind of accounting information indeed there is no authenticity. The same accounting matters, different measurement methods and different accountants will come to different results. First of all, with the accounting information process is developed, it is based on the measurement of a lot. At the same time, it deals with the same accounting matters. it is also different ways of measuring the emphasis. Even if the measured data and the basis of the same, as long as the measurement of different emphases, it will lead to different results. Secondly, the individual understanding of accounting measurement will result in the deviation of accounting information, which is not to say which is good or poor. It depends on the different decision-making direction. Different accounting information is suitable for different decision-making direction.

\section{Problems of Accounting Information Quality}

Selected Communication of Enterprise Information. The selected communication is mainly refers to the internal circulation of enterprise's information flow in a narrow sense, that is to say, the circulation among the various stakeholders of the enterprise. Simply speaking, the flow of information is known as the flow of information among the insiders. The real accounting information is also in circulation among them. As enterprises in order not to let their own enterprise's negative situation is too much, so they will selectively open part of the information, for 
the enterprise adverse information will certainly not be published, the final result is that some people accounting information is complete, but the other part of the opposite. Enterprise management is also the management of accounting information. They manage the collection and verification of the accounting information. Their advantages are self-evident.

Nowadays, the competition of enterprises is mainly refers to the high-tech competition with information and technology. The competition of technology is inevitable. At the same time, the competition of technology is very difficult, because once the technology is mastered, then the company will take the most stringent measures to protect the company. But the competition of information is very easy to do. Because the management of information is always a part of the omission, as long as the other companies to grasp the information, then the business secrets of their own business are completely exposed. Especially some of the interests of the company may cause serious impact on the information, such as financial companies a huge loophole, or problems with the company's stock, and even the company's fiscal problems is industrial and commercial administrative departments to investigate and deal with major issues, which will lead to the company's reputation has plummeted. Even the company's stock will lead to huge fluctuations, resulting in a sharp decline in the company's reputation and so on. Therefore, in spite of the fact that the requirements of the accounting system is due to the true reflection of the company's financial situation, but in some cases, the managers cannot say it all out. The information circulation of the enterprise is selected.

Single Public of Enterprise Information. In the past, the understanding of the enterprise is only profit. No matter what companies are doing, as long as the enterprise is profitable, everything will be fine. But this perspective ignores the social function of the enterprise. The enterprise is not only to create more economic value for the society, but also affect the social atmosphere. Now most of the enterprise's report is said how its economic benefits, how much profit today, or how many assets have increased, but there is little mention of corporate social value, as well as the future direction of the development of the enterprise. With the development of China's socialist market economy and the further progress of reform, the past kind of just blindly pursue economic enterprises will be excluded from the community. The enterprise must withdraw from the market when the situation is serious. In contrast, beneficial to the community of enterprises will be the attention of the community, especially and ordinary people are closely related to the matter of great efforts to the enterprise, but will develop better. In the past, the pursuit of the industrial era is the maximization of the interests, the basic social function of the enterprise is zero. However, with the improvement of the level of awareness of the general public, people require more and more corporate social responsibility, not the economic benefits, users and policy makers will be in the economic interests and social interests into a dilemma situation. It is difficult to make a comprehensive and detailed evaluation of the company.

\section{Effects on Accounting Information Quality of Internal Control Audit}

Fully Master Problems of Accounting Information Quality. Firstly, the accountant should penetrate into the enterprise to comprehensively master the specific situation when doing the internal control audit. Give a simple example, a person is sick, but his specific causes of disease require the accurate grasp and understanding by the doctor. Some patients are afraid or shy to tell the true condition. They do not want to mention the specific etiology, cause the patient himself ill treatment. The purpose of internal control audit is to accurately grasp the specific reasons, through a certain means to understand the real sense of the development of the enterprise. At the same time we should also understand the relevant internal control audit system, as well as the specific development of the situation, including the internal control audit system problems and so on. The most important thing is to master the first-hand data and information and do the relevant statistics and records well.

Correctly Evaluate Problems of Accounting Information Quality. The accountants should confirm the quality of accounting information, monitor the environment with a comprehensive and systematic investigation and control the environment, procedures and system. Only to find the real 
underlying cause of disease, the doctors can take the correct medicine. Only to find out the underlying cause of the quality of accounting information, the managers can carry out the correct reforms rapidly and efficiently to handle the problem.

\section{Conclusion}

To sum up, for the relationship between enterprise internal control audit and accounting information quality problems, we should first of all master the specific performance of enterprise accounting information quality problems and identify the specific cause of accounting quality. At the same time, the accounting staff must have the rational awareness and a comprehensive analysis of the problem. They cannot modify the data deliberately. They must provide the comprehensive and accurate reports to decision layer to let them to make a decision. Secondly, the key to the internal control audit is how to do the audit according to the national laws and regulations, industry standards as well as the accuracy of the internal system of enterprise.

\section{References}

[1] Zhou Lin, Research on the Relationship between Internal Control and Quality of Accounting Information, Dongbei University of Finance and Economics, 2012.

[2] Zhou Handan, Internal Control Audit and Accounting Information Quality, Soochow University, 2013.

[3] Liu Yifang, Huang Zheng, The Effect of the Internal Audit Characteristics on the Accounting Information Quality--An Empirical Evidence of Shenzhen Stock Exchange Main Board Listed Companies from 2009 2012, J., Journal of Northeast Normal University (Philosophy and Social Sciences), 2015(1): 141-146.

[4] You Wenli, On the Internal Control of Chinese Enterprise and the Quality of Accounting Information, Journal of Zhongzhou University, 2014, 31(3):31-35. 